\title{
Pengaruh Minat Baca dan Penguasaan Kosakata terhadap Kemampuan Menulis Teks Eksposisi
}

\author{
Dedeh Juariah $^{1)}$ \\ Universitas Indraprasta PGRI \\ Jalan Nangka No. 58 C/TB. Simatupang, Tanjung Barat, Jakarta Selatan 12530
}

E. Zaenal Arifin')

Universitas Indraprasta PGRI

Jalan Nangka No. 58 C/TB. Simatupang, Tanjung Barat, Jakarta Selatan 12530

\author{
Mamik Suendarti ${ }^{3)}$ \\ Universitas Indraprasta PGRI \\ Jalan Nangka No. 58 C/TB. Simatupang, Tanjung Barat, Jakarta Selatan 12530 \\ dedehjuariah71@gmail.com ${ }^{1)}$
}

\begin{abstract}
The purpose of this study is 1) To determine the effect of interest in reading and mastery of vocabulary together on the ability to write exposition text for state junior high school students in Lebak Regency 2) To determine the effect of reading interest on the ability to write text exposition state junior high school students in Lebak 3 ) To determine the effect of mastery of vocabulary on the ability to write exposition text of junior high school students in Lebak Regency. The research method used was a survey method using correlation and regression analysis techniques. The sample used in this study amounted to 60 students. Based on the results of the hypothesis and data analysis as follows: 1) There is a significant influence of interest in reading and mastery of vocabulary together on the ability to write text exposition students of state junior high schools in Lebak Regency. This can be proven by the Sig value of 0,000 $<0.05$ and $F$ arithmetic $=31,147$. Interest in reading and mastery of vocabulary together accounted for $52.2 \%$ of the variations in the ability to write exposition text. 2) there is a significant influence of reading interest on the ability to write exposition text of state junior high school students in Lebak Regency. this can be proven with the Sig value of $0,000<0.05$ and $t$ arithmetic $=4.672 .3)$. there is a significant influence of vocabulary mastery on the ability to write exposition text of state junior high school students in Lebak Regency. this can be proven by the value of Sig $0.007<0.05$ and t arithmetic $=2.819$.
\end{abstract}

Keywords: Ability to Write Exposition Text, Interest in Reading, Vocabulary Mastery.

\begin{abstract}
Abstrak
Tujuan penelitian ini adalah 1) Untuk mengetahui pengaruh minat baca dan penguasaan kosakata secara bersama-sama terhadap kemampuan menulis teks eksposisi siswa SMP Negeri di Kabupaten Lebak 2) Untuk mengetahui pengaruh minat baca terhadap kemampuan menulis teks eksposisi siswa SMP Negeri di Kabupaten Lebak 3) Untuk mengetahui pengaruh penguasaan kosakata terhadap kemampuan menulis teks eksposisi siswa SMP Negeri di Kabupaten Lebak. Metode penelitian yang digunakan adalah metode survei dengan menggunakan teknik analisis korelasi dan regresi. Sampel yang digunakan dalam penelitian ini berjumlah 60 siswa. Berdasarkan hasil hipotesis dan analisis data sebagai berikut: 1) Terdapat pengaruh yang signifikan minat baca dan penguasaan kosakata secara bersama-sama terhadap kemampuan menulis teks eksposisi siswa SMP Negeri di Kabupaten Lebak. Hal tersebut dapat dibuktikan dengan nilai Sig $0,000<0,05$ dan F hitung $=31,147$. Minat baca dan penguasaan kosakata secara bersama-sama menyumbang sebesar $52,2 \%$ terhadap variasi
\end{abstract}

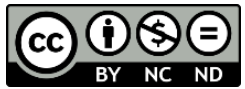




\section{Diskursus: Jurnal Pendidikan Bahasa Indonesia}

Vol. 3, No. 2, Agustus 2020, pp. 120-120

p-ISSN: 2615-4935

e-ISSN: 2615-4943

kemampuan menulis teks eksposisi. 2) Terdapat pengaruh yang signifikan minat baca terhadap kemampuan menulis teks eksposisi siswa SMP Negeri di Kabupaten Lebak. Hal tersebut dapat dibuktikan dengan nilai Sig 0,000 <0,05 dan thitung = 4,672. 3). Terdapat pengaruh yang signifikan penguasaan kosakata terhadap kemampuan menulis teks eksposisi siswa SMP Negeri di Kabupaten Lebak. Hal tersebut dapat dibuktikan dengan nilai Sig 0,007 <0,05 dan thitung = 2,819.

Kata Kunci: Kemampuan Menulis Teks Eksposisi, Minat Baca, Penguasaan Kosakata.

\section{PENDAHULUAN}

Berdasarkan kurikulum 2013 sebagai awal pengenalan belajar siswa SMP kelas VIII harus menguasai teks eksposisi. Pelajar agar dapat berpikir secara kritis, memperdalam daya tanggap atau persepsi, memecahkan masalah, dan kreatif dalam menuangkan gagasan dalam bentuk bahasa tulis harus menguasai keterampilan menulis.

Nurgiyantoro (2001:296) mengemukakan bahwa keterampilan menulis bila dibandingkan dengan tiga keterampilan lain yaitu menyimak, berbicara, dan membaca merupakan kemampuan yang lebih sulit dikuasai.

Kegemaran dan minat baca dapat meningkatkan penguasaan kosakata dan keterampilan menulis teks eksposisi siswa. Pada akhirnya siswa akan memperoleh sejumlah konsep, pengetahuan, maupun teknologi.

Peranan perpustakaan sekolah selain sumber ilmu pengetahuan juga merupakan salah satu di antara beberapa faktor yang dapat memengaruhi terwujudnya minat baca yang tinggi. Sekolah yang perpustakaannya hidup akan berkembang pesat dan lebih maju, sebaliknya sekolah yang perpustakaannya mati pengembangan ilmu pengetahuan dari sekolah tersebut juga akan terhambat. Kegiatan membaca akan bermakna dan berkualitas apabila didorong oleh minat baca yang tinggi. Minat baca yang rendah diduga sebagai pemicu rendahnya penguasaan kosakata.

Peranan buku dalam kehidupan sekarang masih belum tergeser, meskipun teknologi telah menemukan alat-alat audio-visual yang dapat menyampaikan banyak hal lebih cepat dan lebih praktis daripada buku. Rosidi (2016:80) mengemukakan bahwa hal-hal tentang kebajikan dan kebijaksanaan tidak dapat disampaikan melalui alat-alat audio-visual karena hanya terbatas kepada menyampaikan pengetahuan-pengetahuan mengenai benda-benda yang berbentuk.

Setiap pemakai bahasa sangat memerlukan penguasaan kosakata, sebagai alat penyalur gagasan, penguasaan terhadap sejumlah kosakata dan memperlancar informasi yang diperlukan melalui komunikasi lisan maupun tulisan. Kosakata pada prinsipnya dipelajari siswa bertujuan agar dapat menyimak, berbicara, membaca, dan menulis dengan baik.

Peserta didik masih banyak yang tidak dapat memahami makna kata-kata yang dibaca sesuai dengan konteks bacaan, sehingga menghambat siswa untuk memahami makna dalam satuan yang lebih besar, yakni kalimat atau paragraf dalam proses membaca, hal itulah yang menyebabkan masih rendahnya penguasaan kosakata yang dimiliki peserta didik. Penguasaan kosakata merupakan unsur terpenting yang harus dimiliki peserta didik dalam belajar bahasa, karena bagaimanapun fungsi dari kosakata itu sendiri adalah sebagai unsur pembentuk

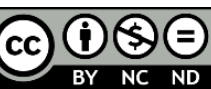

Creative Commons Attribution-NonCommercial-NoDerivatives 4.0 International License 
kalimat dan mengutarakan isi pikiran dan perasaan dengan sempurna baik secara lisan maupun tertulis.

Penguasaan kosakata dalam satu bahasa berhubungan dengan jumlah kata yang harus dikuasai agar seseorang dapat menggunakan bahasa untuk berkomunikasi dan pemilihan kata serta pemakaiannya sesuai dengan konteks komunikasi. Latihan menulis dalam pembelajaran bahasa Indonesia dapat membiasakan siswa untuk menerapkan pengetahuan kebahasaan, seperti tata bahasa, kosakata, gaya bahasa, ejaan, dan sebagainya.

Tarigan (2018:3) mengatakan bahwa berkomunikasi secara tidak langsung dan tidak secara tatap muka dengan orang lain merupakan suatu keterampilan berbahasa menulis yang produktif dan ekspresif.

Keraf (2002:3) mengatakan bahwa eksposisi atau pemaparan adalah salah satu bentuk tulisan atau retorika yang berusaha untuk menerangkan dan menguraikan suatu pokok pikiran, yang dapat memperluas pandangan atau pengetahuan seseorang yang membaca uraian tersebut. Selain itu, Hasani (2005:300) juga mendefenisikan bahwa eksposisi sering digunakan dalam menyampaikan uraian ilmiah dan tidak berusaha memengaruhi pendapat pembaca dalam bentuk tulisan.

Kosasih (2018:75) dalam buku paket bahasa Indonesia kelas VIII mengemukakan struktur teks eksposisi terbagi menjadi tiga bagian, yaitu:

1. Tesis, yakni berupa pengenalan isu, masalah, ataupun pandangan penulis secara umum tentang topik yang akan dibahasnya.

2. Rangkaian argumen, berupa sejumlah pendapat atau argumen penulis sebagai penjelasan atas tesis yang dikemukakan sebelumnya. Pada bagian ini dikemukakan pula sejumlah fakta yang memperkuat argumen-argumen penulis.

3. Penegasan ulang atau sering disebut penutup atau simpulan sebagai perumusan kembali secara ringkas.

Kamus Besar Bahasa Indonesia (KBBI) mengemukakan bahwa membaca berasal dari kata baca yaitu "melihat serta memahami isi dari apa yang tertulis" (dengan melisankan atau hanya dalam hati). Tarigan (2007:7) mengatakan bahwa membaca untuk memperoleh pesan yang disampaikan oleh penulis melalui media kata-kata atau bahasa tulis itu merupakan suatu proses yang harus dilakukan oleh pembaca. Dalman (2013:5) mengatakan bahwa suatu kegiatan atau proses kognitif yang berupaya untuk menemukan berbagai informasi yang terdapat dalam tulisan itu merupakan kegiatan membaca.

Suatu rasa lebih suka dan ada rasa ketertarikan pada suatu kegiatan atau aktivitas yang ditunjukkan dengan keinginan atau kecenderungan untuk memperhatikan aktivitas tersebut tanpa ada yang menyuruh, dilakukan dengan kesadarannya, dan diikuti dengan rasa senang itu disebut dengan minat. Seorang anak yang memiliki minat membaca tidak muncul begitu saja, tetapi melalui proses yang panjang dan tahapan perubahan yang muncul secara teratur dan berkesinambungan.

Rahim (2008:16) mengatakan bahwa minat baca adalah suatu keinginan yang kuat disertai usaha-usaha seseorang untuk membaca. Seseorang yang mempunyai minat membaca yang kuat akan diwujudkan dalam kesediaannya untuk 
mendapat bahan bacaan dan kemudian membacanya atas kesadarannya sendiri tanpa ada paksaan dari orang lain.

Bunata (2004:142) menyebutkan bahwa ada beberapa faktor yang sangat menentukan dalam minat baca, sebagai berikut:

1. Faktor lingkungan keluarga.

Di tengah kesibukan sebaiknya orang tua menyisihkan waktu untuk menemani anaknya membaca buku, dengan begitu orang tua dapat memberikan contoh yang baik dalam meningkatkan kreativitas membaca anak.

2. Faktor kurikulum dan pendidikan sekolah yang kurang kondusif.

Kurikulum tidak secara tegas mencantumkan kegiatan membaca dalam suatu bahan kajian, serta para tenaga kependidikan baik sebagai guru, dosen maupun para pustakawan yang tidak memberikan motivasi pada anak-anak peserta didik bahwa membaca itu penting untuk menambah ilmu pengetahuan, melatih berpikir kritis, menganalisis persoalan, dan sebagainya.

3. Faktor infrastruktur masyarakat yang kurang mendukung peningkatan minat baca masyarakat.

Kurangnya minat baca masyarakat ini bisa dilihat dari kebiasaan sehari-hari. Banyak orang yang lebih memilih menghabiskan uang demi hal lain daripada membeli buku. Orang juga lebih suka pergi ke tempat hiburan daripada pergi ke toko buku. Mereka hanya pergi ke toko buku atau perpustakaan bila memang diperlukan saja.

4. Faktor keberadaan dan kejangkauan bahan bacaan.

Sebaiknya pemerintah daerah mengadakan program perpustakaan keliling atau perpustakaan tetap di tiap-tiap daerah agar lebih mudah dijangkau oleh masyarakat.

Tarigan (2015:3) mengatakan bahwa kosakata dasar (basic vocabulary) adalah kata-kata yang tidak mudah berubah atau sedikit kemungkinan dipungut dari bahasa lain. Sedangkan Kridalaksana (1993:19) mengatakan bahwa kosakata adalah 1) daftar kata yang disusun seperti kamus, tetapi dengan penjelasan yang singkat dan praktis; 2) komponen bahasa yang memuat secara informasi tentang makna dan pemakaian kata dalam bahasa; 3) kekayaan kata yang dimiliki seorang pembicara, penulis atau suatu bahasa. lain:

Materi kosakata yang dapat digunakan dalam pembelajaran kosakata antara

1. Idiom

Finoza (2013:144) mengatakan bahwa idiom menurut Moeliono adalah suatu ungkapan bahasa yang artinya tidak secara langsung dapat dijabarkan dari unsur-unsurnya. Idiom berupa gabungan kata (frase) yang maknanya sudah menyatu dan tidak dapat ditafsirkan dengan makna unsur pembentuknya. Konstruksi tersebut tidak dapat diganti atau diubah, maka konstruksi semula menjadi tidak tepat atau berbeda. Sebagian idiom berupa kelompok kata, misalnya gulung tikar, adu domba, muka tembok.

2. Sinonim

Arifin (2018:67) mengatakan bahwa sinonim adalah dua kata atau lebih yang maknanya sama atau mirip, tetapi bentuknya berlainan. 
3. Antonim

Arifin (2018:68) mengatakan bahwa antonim adalah kata yang berlawanan atau beroposisi, seperti panjang $><$ pendek; besar $><$ kecil.

4. Homonim

Arifin (2018:68) mengatakan bahwa istilah homonim berupa dua kata atau lebih yang sama ejaan dan lafalnya, tetapi maknanya berbeda karena asalnya berlainan. Istilah homonim dapat dibedakan menjadi homograf dan homofon. Misalnya: $b u k u=$ sendi bamboo, $b u k u=$ kitab; $k a l i=$ sungai, $k a l i=$ lipat."

5. Denotasi

Tarigan (2006:56) mengatakan bahwa denotasi adalah sesuatu kata merupakan makna-makna yang bersifat umum, tradisional, dan presedensia, atau makna sebenarnya.

6. Konotasi

Tarigan (2006:52) mengatakan bahwa konotasi adalah pancaran impresi-impresi yang tidak dapat dibaca dan tidak dapat dinyatakan secara jelas. Konotasi juga berarti segala sesuatu yang kita pikirkan apabila kita melihat kata tersebut, yang mungkin dan tidak mungkin sesuai dengan makna sebenarnya. Konotasi dapat pula diartikan sebagai makna tambahan dari makna sebenarnya.

7. Hiponim

Arifin (2018:70) istilah hiponim ialah bentuk yang maknanya terangkum dalam hiperonim, atau subordinatnya, atau superordinatnya, yang mempunyai makna yang lebih luas. Kata mawar, melati, cempaka, misalnya masing-masing disebut hiponim terhadap kata bunga yang menjadi hiperonim atau superordinatnya.

\section{METODE}

Penelitian ini dilaksanakan pada tiga sekolah yaitu SMP Negeri 1 Sajira, SMP Negeri 2 Sajira, dan SMP Negeri 4 Sajira Kecamatan Sajira Kabupaten Lebak. Metode yang digunakan dalam penelitian ini adalah metode survei dengan menggunakan teknik analisis korelasi regresi ganda. Metode ini memberikan gambaran tentang variabel-variabel yang ditemukan, sekaligus menyelidiki hubungan dan pengaruh antara variabel.

Dalam penelitian ini penulis memperoleh populasi yaitu jumlah seluruh siswa kelas VIII SMP Negeri di Kabupaten Lebak, yaitu pada SMP Negeri 1 Sajira, SMP Negeri 2 Sajira, dan SMP Negeri 4 Sajira Kabupaten Lebak sebanyak 503 siswa.

Arikunto (2013:112) mengatakan bahwa apabila subjeknya kurang dari 100 lebih baik diambil semua, maka penelitiannya merupakan penelitian populasi. Jika jumlah subjeknya besar dapat diambil $10-15 \%$ atau $20-25 \%$ atau lebih. Adapun dasar pengambilan sampel dalam penelitian ini penulis menggunakan pendapat di atas.

Berdasarkan pendapat tersebut, maka dari 503 siswa populasi tersebut penulis mengambil $12 \%$ untuk dijadikan sampel dengan penghitungan (503 x $12 \%$ 
$=60,36$, dibulatkan menjadi 60). Jumlah sampel dalam penelitian ini ditetapkan sebanyak 60 siswa yang dilakukan secara acak (random).

Teknik pengumpulan data untuk variabel minat baca $\left(\mathrm{X}_{1}\right)$ dengan menggunakan kuesioner atau daftar pernyataan yang berupa pernyataan skala sikap yang terdiri atas 20 butir pernyataan positif dan negatif. Penskoran menggunakan skala Likert dengan 5 alternatif jawaban. Instrumen untuk mengukur minat baca yaitu berupa pernyataan skala sikap dengan pilihan sangat setuju (SS), setuju (S), ragu-ragu (R), tidak setuju (TS), dan sangat tidak setuju (STS).

Teknik pengumpulan data untuk variabel penguasaan kosakata $\left(\mathrm{X}_{2}\right)$ menggunakan tes butir soal pilihan ganda sebanyak 20 soal. Penilaian dilakukan dengan penskoran. Setiap soal yang jawabannya benar diberi skor 1 (satu) sedangkan jawaban yang salah diberi skor 0 (nol).

Teknik pengumpulan data untuk variabel kemampuan menulis teks eksposisi (Y) menggunakan tes tertulis dengan penskoran 1-100.

\section{Teknik Analisis Data}

1. Analisis deskriptif

Pembuatan tabel distribusi frekuensi dan penyajian grafik polygon serta histogram. Sedangkan ukuran pusat, letak dan simpangan diantaranya dapat ditentukan dengan rumus-rumus berikut:

a. Menentukan Mean rata-rata (Y),

b. Menentukan Modus (MO), dengan

c. Variansi (SD) dan simpangan baku

Untuk perhitungan statistik deskriptif dalam penelitian ini diselesaikan dengan menggunakan bantuan program komputer SPSS statistik v20.

2. Uji Persyaratan analisis

a. Uji Normalitas

Uji normalitas ini bertujuan untuk mengetahui apakah data hasil pengumpulan berdistribusi normal atau tidak. Hal ini akan berpengaruh pada proses lanjutan analisis statistik. Jika data berdistribusi normal, maka analisis dilanjutkan menggunakan statistik parametrik. Uji normalitas dapat dilakukan menggunakan analisis Kolmogorov Smirnov dalam SPSS statistik versi 20. Distribusi data dikatakan normal jika nilai sig KS >0,05.

b. Uji Linieritas

Pengujian linieritas garis regresi dalam penelitian ini digunakan Uji F, Dalam praktiknya akan digunakan bantuan program SPSS statistik v20. untuk menghitung uji linieritas, yaitu dengan melihat besarnya nilai koefisien sig pada Deviation From linierity. Kriteria pengujian linieritasnya adalah sebagai berikut:

Jika sig > 0,005 maka garis regresi linier

Jika sig $\leq 0,005$ maka garis tersebut tidak linier

c. Uji Multikolinieritas

Uji Multikolinieritas dalam rangka menguji apakah dalam model ganda ditemukan adanya korelasi antar variabel bebas. Dalam analisis yang baik disyaratkan tidak terjadi kolinieritas atau multikolinieritas di antara variabel bebas. Untuk mengetahui terjadi kolinieritas atau multikolinieritas 
di antara variabel bebas dalam suatu model regresi dilakukan dengan melihat atau menguji nilai VIF (Variance Inflation Factor) atau nilai TOL.

3. Uji Hipotesis Penelitian (Analisis Inferensial)

Setelah keseluruhan uji persyaratan analisis data dipenuhi dan diketahui data layak untuk diolah lebih lanjut, maka langkah berikutnya adalah menguji masing-masing hipotesis yang telah diajukan. Pengujian hipotesis menggunakan teknik korelasi partial dan korelasi ganda, serta regresi linier sederhana dan regresi linier ganda. Dalam praktiknya, untuk perhitungan dan pengujian korelasi dan regresi baik partial maupun ganda akan digunakan bantuan program SPSS statistik v20. Adapun kriteria pengujiannya adalah sebagai berikut:

a. Analisis Korelasi

Perhitungan dan Pengujian Signifikansi Koefisien Korelasi Partial hasil perhitungan koefisien korelasi partial bisa dilihat atau output. Program SPSS melalui analisis korelasi pada tabel Correlation. Signifikasi dari koefisien korelasi tersebut dinyatakan oleh keterangan yang ada di bawah tabel tersebut yaitu:

1) Untuk tanda ** (dua bintang) maka koefisien korelasi tersebut signifikan pada taraf nyata $1 \%$

2) Untuk tanda * (satu bintang) maka koefisien korelasi tersebut signifikan pada tarif nyata $5 \%$ tidak signifikan pada tarif nyata $1 \%$

3) Untuk yang tidak ada bintangnya maka koefisien korelasi tersebut tidak signifikan

Perhitungan dan pengujian Signifikasi koefisien korelasi ganda. Hasil perhitungan koefisien korelasi ganda bisa dilihat dari output program SPSS melalui analisis regresi yakni pada table "Model Summary" signifikan dari koefisien korelasi tersebut diuji secara manual atau dengan bantuan komputer melalui program aplikasi Microsoft Excel.

b. Analisis Regresi

1) Perhitungan Persamaan Garis Regresi

Perhitungan garis regresi bisa dilihat dari output program SPSS melalui analisis regresi yakni pada tabel Coefficients. Koefisienkoefisien persamaan garis regresi ditunjukkan oleh bilangan-bilangan yang ada pada kolom B untuk Unstandardized.

2) Pengujian Signifikasi Regresi

Regresi Partial

Untuk pengujian signifikasi regresi partial dilakukan dengan memperhatikan nilai pada kolom $\mathbf{t}$ atau kolom Sig pada tabel Coefficients. Untuk regresi partial pengaruh $\mathbf{x}_{\mathbf{1}}$ terhadap Y digunakan baris nilai $\mathbf{t}$ dan Sig pada baris variabel $\mathbf{x}_{\mathbf{1}}$ sedangkan untuk regresi partial pengaruh $\mathbf{x}_{\mathbf{1}}$ terhadap $\mathbf{Y}$ digunakan baris nilai $\mathbf{t}$ dan Sig pada baris variabel $\mathbf{x}_{\mathbf{1}}$. Jika digunakan kolom Sig maka kriteria signifikasinya adalah: "Jika Sig < 0,05 maka regresi tersebut signifikan."

Jika digunakan kolom t maka kriteria signifikasinya adalah:

"Jika $t_{\text {hitung }}>\mathbf{t}_{\text {tabel }}$ maka regresi tersebut signifikan" Untuk Regresi Ganda 
Hasil pengujian signifikasi regresi ganda bisa dilihat dari output program SPSS melalui analisis regresi yakni pada tabel ANOVA $^{\mathbf{b}}$ kolom $\mathrm{F}$ atau Sig. Kriteria signifikasinya adalah: Jika digunakan kolom Sig maka kriteria signifikasinya adalah: "Jika Sig < 0,05 maka garis regresi tersebut signifikan"

\section{HASIL DAN PEMBAHASAN}

\section{Hasil}

\section{Pengujian Hipotesis Penelitian}

Pengujian hipotesis dilakukan dengan teknik analisis regresi linier berganda. Perhitungan dilakukan dengan bantuan program SPSS, hasil pengujian disajikan dalam tabel model Summary, Anova, dan coefficient sebagai berikut.

Tabel 1. Koefisien Korelasi Ganda, Koefisien Determinasi, Minat Baca dan Penguasaan Kosakata Secara Bersama-sama terhadap Kemampuan Menulis

\section{Model Summary ${ }^{b}$}

Model R R Square Adjusted R Square Std. Error of the Estimate

$\begin{array}{llll}1 & .723^{\mathrm{a}} & .522 & .505\end{array}$

4.410

a. Predictors: (Constant), Penguasaan Kosakata, Minat Baca

b. Dependent Variable: Kemampuan Menulis Teks Eksposisi

Tebel 2. Pengujian Koefisien Korelasi Ganda

\begin{tabular}{|c|c|c|c|c|c|c|}
\hline \multicolumn{7}{|c|}{ ANOVA $^{\mathrm{a}}$} \\
\hline & Model & Sum of Squares & df & Mean Square & $\mathrm{F}$ & Sig. \\
\hline \multirow{3}{*}{1} & Regression & 1211.336 & 2 & 605.668 & 31.147 & $.000^{\mathrm{b}}$ \\
\hline & Residual & 1108.397 & 57 & 19.446 & & \\
\hline & Total & 2319.733 & 59 & & & \\
\hline
\end{tabular}

a. Dependent Variable: Kemampuan Menulis Teks Eksposisi

b. Predictors: (Constant), Penguasaan Kosakata, Minat Baca

Tabel 3. Koefisien Korelasi Ganda dan Tingkat Signifikasi Regresi

\section{Coefficients $^{\mathrm{a}}$}

\begin{tabular}{|c|c|c|c|c|c|}
\hline \multirow[t]{2}{*}{ Model } & \multicolumn{2}{|c|}{$\begin{array}{l}\text { Unstandardized } \\
\text { Coefficients }\end{array}$} & $\begin{array}{l}\text { Standardized } \\
\text { Coefficients }\end{array}$ & \multirow[t]{2}{*}{$\mathrm{t}$} & \multirow[t]{2}{*}{ Sig. } \\
\hline & $\mathrm{B}$ & Std. Error & Beta & & \\
\hline (Constant) & 28.738 & 5.945 & & 4.834 & .000 \\
\hline Minat Baca & .455 & .097 & .509 & 4.672 & .000 \\
\hline $\begin{array}{l}\text { Penguasaan } \\
\text { Kosakata }\end{array}$ & .185 & .065 & .307 & 2.819 & .007 \\
\hline
\end{tabular}

a. Dependent Variable: Kemampuan Menulis Teks Eksposisi 


\section{Pembahasan}

\section{Pengaruh Minat baca dan Penguasaan Kosakata Secara Bersama-Sama dengan Kemampuan Menulis Teks Eksposisi}

Hasil pengujian diperoleh nilai Sig $=0,000<0,05$ dan $F_{\text {hitung }}=31,147$. Hal ini menunjukkan variabel minat baca dan variabel penguasaan kosakata secara bersama-sama memiliki hubungan yang signifikan dengan variabel kemampuan menulis teks eksposisi. Selanjutnya berdasarkan persamaan regresi ganda dapat diartikan setiap kenaikan satu unit minat baca dan sekaligus dengan kenaikan satu unit variabel penguasaan kosakata akan diikuti dengan kenaikan kemampuan menulis sebesar $(0.455+0.185)=0,640$ unit.

Minat baca memiliki hubungan yang signifikan dengan keempat keterampilan berbahasa yakni menyimak, membaca, mendengar, dan menulis. Berkaitan dengan keterampilan menulis eksposisi adalah suatu jembatan yang sempurna untuk membuat dua kategori tentang penulisan-penulisan tanggapan dan penulisan berita, karena model penulisan tersebut paling banyak digunakan para kalangan siswa. Dengan demikian dapat diartikan semakin baik minat baca dan penguasaan kosakata, maka kemampuan menulis eksposisi siswa akan semakin baik juga.

\section{Pengaruh Minat Baca terhadap Kemampuan Menulis Eksposisi}

Berdasarkan hasil pengujian diperoleh Sig $=0,000<0,05$ dan $\mathrm{t}_{\text {hitung }}=4,672$, maka dapat dinyatakan terdapat pengaruh yang signifikan variabel minat baca terhadap variabel kemampuan menulis teks eksposisi. Setiap kenaikan satu unit minat baca akan diikuti dengan kenaikan kemampuan menulis teks eksposisi sebesar 0,455unit, ceteris paribus atau variabel penguasaan kosakata tidak berubah.

Buku dengan judul Pengajar Pemahaman Bahasa Manusia oleh Soejono mengungkapkan temuan bahwa anak usia lima tahun sudah bisa menguasai minimal lebih banyak daripada verba, setelah itu adjektiva, dan kata fungsi di urutan keempat. Pemahaman kosakata pada anak tergantung pada lingkungan anak beradaptasi dan sesuai dengan tingkatan umurnya, bila sering diucapkan dan didengar anak, akan mudah dan cepat dipahami. Untuk dapat menyampaikan gagasan dan ide kepada orang lain melalui tulisan seorang penulis haruslah terampil memanfaatkan grafologi, struktur bahasa, dan kosakata sebab penguasaan kosakata sangat dibutuhkan dalam kegiatan menulis untuk melahirkan sebuah tulisan atau karya sastra. Menulis erat kaitannya dengan proses menerjemahkan ide menjadi simbol atau lambang bahasa. Menulis adalah suatu proses kreatif memindahkan gagasan ke dalam lambang-lambang tulisan Menulis merupakan kegiatan produktif dan ekspresif salah satunya adalah menulis karya fiktif maupun non-fiktif.

Dari informasi kuantitatif dan teori tersebut maka peneliti menyimpulkan bahwa terdapat pengaruh yang signifikan minat baca terhadap kemampuan menulis teks eksposisi.

\section{Pengaruh Penguasaan Kosakata terhadap Kemampuan Menulis Eksposisi}

Berdasarkan hasil pengujian diperoleh nilai Sig $=0,007<0,05$ dan $\mathrm{t}_{\text {hitung }}=$ 2,819, maka dapat dinyatakan terdapat pengaruh yang signifikan variabel 
penguasaan kosakata dengan variabel kemampuan menulis teks eksposisi. Setiap kenaikan satu unit penguasaan kosakata akan diikuti dengan kenaikan kemampuan menulis sebesar 0,185unit, ceteris paribus atau variabel minat baca tidak berubah.

Seorang siswa harus memiliki pengetahuan dan wawasan yang luas tentang topik yang menjadi pembahasan. Wawasan itu tercermin dalam kemampuannya menggunakan kata-kata ilmiah atau kata-kata kajian secara tepat sesuai konteks pembicaraan. Banyaknya kata kajian yang dipergunakan tidak secara tepat dapat menjadi ukuran luas tidaknya wawasan siswa. Siswa dapat menyusun sebuah wacana yang efektif baik melalui media tulisan maupun lisan pasti harus dapat menguasai kosakata dalam bahasa Indonesia serta memahami suatu cara menyampaikan informasi dengan memilih wacana atau bentuk alinea yang berupa rangkaian kata-kata dalam struktur kosakata yang jelas.

Dari informasi kuantitatif dan teori tersebut maka peneliti berasumsi bahwa terdapat pengaruh yang signifikan antara penguasaan kosakata dengan kemampuan menulis teks eksposisi.

\section{SIMPULAN}

Berdasarkan hasil analisis dan pembahasan maka dapat disimpulkan terdapat pengaruh yang signifikan minat baca dan penguasaan kosakata secara bersamasama terhadap kemampuan menulis teks eksposisi siswa SMP Negeri di Kabupaten Lebak. Hal tersebut dapat dibuktikan dengan nilai Sig $0,000<0,05$ dan $F_{\text {hitung }}=$ 31,147. Minat baca dan penguasaan kosakata secara bersama-sama menyumbang sebesar 52,2\% terhadap variasi kemampuan menulis teks eksposisi. Terdapat pengaruh yang signifikan minat baca terhadap kemampuan menulis teks eksposisi siswa SMP Negeri di Kabupaten Lebak. Hal tersebut dapat dibuktikan dengan nilai Sig $0,000<0,05$ dan thitung= 4,672. Terdapat pengaruh yang signifikan penguasaan kosakata terhadap kemampuan menulis teks eksposisi siswa SMP Negeri di Kabupaten Lebak. Hal tersebut dapat dibuktikan dengan nilai Sig 0,007 $<0,05$ dan thitung= 2,819.

\section{DAFTAR PUSTAKA}

Arifin, E. Z. (2018). Wacana transaksional dan interaksional dalam bahasa Indonesia. Tangerang: Pustaka Mandiri.

Arikunto, S. (2013). Produser penelitian suatu pendekata praktik. Jakarta: Rineka Cipta.

Bunata, M. (2004). Buku, mendongeng dan minat membaca. Jakarta: Pustaka Tangga.

Dalman. (2013). Keterampilan membaca, Jakarta: Raja Grafindo Persada

Departemen Pendidikan Nasional. (2000). Kamus Besar Bahasa Indonesia, Pusat Bahasa. Jakarta: Balai Pustaka.

Finoza, L. (2013). Komposisi bahasa Indonesia. Jakarta: Diksi.

Hasani, A. (2005). Ihwal menulis. Jakarta: Untira Press.

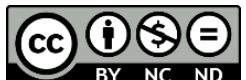

Creative Commons Attribution-NonCommercial-NoDerivatives 4.0 International License 
Keraf, G. (2002). Eksposisi dan dekripsi komposisi lanjutan II. Jakarta: Nusa Indah. Kosasih, E. (2018). Bahasa Indonesia SMP/MTs Kelas VIII. Jakarta: Kementerian Pendidikan dan Kebudayaan.

Kridalaksana, H. (1993). Kamus linguistik (Edisi ketiga). Jakarta: Gramedia Pustaka Utama.

Nurgiyantoro, B. (2001). Penilaian dalam pembelajaran bahasa dan sastra. Yogyakarta: BPFE Yogyakarta.

Rahim, P. (2008). Pengajaran membaca di sekolah dasar. Jakarta: Bumi Aksara.

Rosidi, A. (2016). Pembinaan minat baca. Bandung: Remaja Rosdakarya.

Tarigan, H. G. (2006). Pengajaran semantik. Bandung: Change Publication Design.

Tarigan, H. G. (2015). Pengajaran kosakata. Bandung: Angkasa.

Tarigan, H. G. (2018). Menulis sebagai suatu keterampilan berbahasa. Bandung: Angkasa. 